\title{
Topography of NPY-, Somatostatin-, and VIP-Immunoreactive, Neuronal Subpopulations in the Guinea Pig Celiac-Superior Mesenteric Ganglion and Their Projection to the Pylorus
}

\author{
B. Lindh, T. Hökfelt, L.-G. Elfvin, L. Terenius, ${ }^{\star}$ J. Fahrenkrug, $†$ R. Elde, $\ddagger$ and M. Goldstein $\S$ \\ Departments of Anatomy and Histology, Karolinska Institutet, Stockholm, Sweden, *Department of \\ Pharmacology, Uppsala University, Uppsala, Sweden, †Department of Clinical Chemistry, Bispebjerg Hospital, \\ Copenhagen, Denmark, fDepartment of Anatomy, University of Minnesota, Minneapolis, Minnesota, and the \\ §Department of Psychiatry, New York University Medical Center, New York, New York
}

The topography of the peptidergic neuronal subpopulations in the guinea pig celiac-superior mesenteric ganglion was studied analyzing the distribution of immunoreactivity to neuropeptide Y (NPY), somatostatin (SOM), and vasoactive intestinal polypeptide (VIP)/polypeptide HI (PHI). For comparison, the ganglion was also studied using antisera against the 2 catecholamine-synthesizing enzymes tyrosine hydroxylase (TH) and dopamine $\beta$-hydroxylase (DBH). Approximately 65\% of the neuronal cell bodies contained NPY-like immunoreactivity (NPY-LI), whereas $25 \%$ of the principal ganglion cells contained SOM-like immunoreactivity (SOM-LI). Though occasional cells were found to contain both NPY-LI and SOM-LI, these peptides had a complementary distribution in the ganglion, with NPY cells in the celiac poles and SOM cells in the superior mesenteric pole. The vast majority of both the NPYand SOM-positive cells also contained TH-like immunoreactivity (TH-LI), confirming their catecholaminergic, presumably noradrenergic, nature. Some noradrenergic neurons seemed to lack NPY- and SOM-LI. Small numbers of VIP/PHI-containing cell bodies were found in areas where the NPY-immunoreactive neurons predominated. Many of the VIP/PHI-positive cells contained NPY-LI and occasionally also TH-LI.

The immunohistochemical markers were also observed in fibers. Thus, a comparatively weak NPY-LI was seen in smooth fibers, probably representing axons and axon bundles. SOMLI was seen in a similar type of fiber but also in more strongly fluorescent fibers with a varicose appearance. The latter fibers were observed only in the SOM-dominated part of the ganglion, often surrounding the ganglion cells. Varicose fibers with a similar distribution containing DBH-like immunoreactivity (DBHLI) were also seen. In addition, DBH- and TH-LI were seen in smooth axonlike processes. VIP-positive fibers exhibited a very dense fiber network, almost exclusively related to the SOM celldominated part of the ganglion.

The projection of the postganglionic sympathetic neurons was studied with special reference to the pylorus using a combination of retrograde axonal tracing and indirect immunofluorescence techniques. Seventy-two hours after injection of the fluorescent tracer Fast Blue into the pyloric sphincter, labeled

\footnotetext{
Received Oct. 28, 1985; revised Jan. 23, 1986; accepted Jan. 24, 1986.

The skillful technical assistance of Ms. A.-S. Höijer and Ms. W. Hiort and the excellent secretarial help of Ms. M. Gottfridsson, Ms. M. Jepsen, and Ms. M.

Rapp are gratefully acnowledged. This study was supported by grants from the Karolinska Institutet and the Swedish Medical Research Council (12X-5189, 04X2887), Ruth and Richard Julins Stiftelse and Alice and Knut Wallenbergs Stiftelse. Correspondence should be addressed to Björn Lindh, Department of Anatomy, Karolinska Institutet, Box 60 400, S-104 01 Stockholm, Sweden.
}

Copyright (c) 1986 Society for Neuroscience $0270-6474 / 86 / 082371-13 \$ 02.00 / 0$ neurons were found in the ganglion. By comparing the Fast Blue-labeled cells with the immunoreactive cell bodies, neurons containing both dye and NPY- or SOM-LI were observed. In elution-restaining experiments, it was established that the majority of these cells were also immunoreactive to $\mathbf{T H}$, indicating that they produce noradrenaline. Occasional cells that contained the fluorescent tracer and NPY-LI seemed to lack THLI. Some Fast Blue-containing cells with TH-LI apparently lacked both NPY- and SOM-LI.

The guinea pig pylorus has extrinsic and intrinsic innervation. The extrinsic innervation is extensive and consists of both motor and sensory components. The motor fibers originate from cell bodies in the dorsal motor nucleus of the vagus and the celiacsuperior mesenteric ganglion. In a recent detailed study of the origin of the extrinsic innervation of the guinea pig pylorus using the HRP axonal tracing technique, postganglionic sympathetic neurons located in the celiac-superior mesenteric ganglion were found to be retrogradely labeled after application of HRP into the pylorus (Elfvin and Lindh, 1982).

In recent years a number of small biologically active peptides with a presumed neuromodulator-neurotransmitter function have been identified within the sympathetic nervous system. In the celiac-superior mesenteric ganglion of the guinea pig, cell bodies containing immunoreactivity to somatostatin (SOM) (Hökfelt et al., 1977a) and vasoactive intestinal polypeptide (VIP) (Hökfelt et al., 1977b) - as well as a pancreatic polypeptide (PP)-like peptide, presumably neuropeptide Y (NPY) (Lundberg et al., 1982a, 1983)-have been demonstrated. There is strong evidence that SOM-like immunoreactivity (LI) and NPY-LI coexist with noradrenaline in some of thesc postganglionic sympathetic neurons (Hökfelt et al., 1977a; Lundberg et al., 1982a, 1983). SOM is the growth hormone release-inhibiting factor, which originally was discovered by Krulich and collaborators (1968) and which was then isolated and characterized as a tetradecapeptide by Brazeau et al. (1973). Further investigations revealed that SOM is not exclusively localized to the hypothalamus but has a wide distribution in both CNS and PNS (Hökfelt et al., 1978). VIP was characterized by Said and Mutt (1970; Mutt and Said, 1974), and recently it has been demonstrated that the peptide HI (PHI) (Tatemoto and Mutt, 1980, 1981), which is structurally similar to VIP, is produced from the same precursor as VIP (Itoh et al., 1983). NPY was isolated from porcine brain and characterized as a 36 amino acid residue long peptide (Tatemoto, 1982; Tatemoto et al., 1982). Further investigations have revealed the presence of NPY-LI not only in peripheral noradrenergic (NA) neurons (Lundberg et al., 1983), but also in central catecholaminergic neurons (Everitt et al., 1984). 
The terminal areas of the above-mentioned peptidc-containing neurons in the celiac-superior mesenteric ganglion are not completely known, but among others a projection to the pylorus seems plausible, since it is known that the pylorus receives a prominent innervation of postganglionic sympathetic neurons (Costa and Gabella, 1971; Elfvin and Lindh, 1982; Gabella, 1979) and that peptide-containing nerves are abundant in this region (Schultzberg et al., 1980). The aim of the present study was to identify the peptide content in the neurons of the celiacsuperior mesenteric ganglion and to determine which of these neurons project to the guinea pig pylorus using a combination of retrograde axonal tracing and indirect immunofluorescence techniques (Hökfelt et al., 1983; Skirboll et al., 1984). In an earlier study using this technique on the sensory innervation of the guinea pig pylorus, it was found that a substantial population (about $60 \%$ ) of dorsal root ganglion cells projecting to the pylorus contain substance P-LI (Lindh et al., 1983). Some sensory vagal nerves projecting to the pylorus were also found to be substance $\mathrm{P}$-immunoreactive.

\section{Materials and Methods}

All experiments were performed on male guinea pigs (body weight 200$300 \mathrm{gm}$ ) under Stesolid (Dumex, Copenhagen, Denmark) and Hypnorm Vet (Leo, Ilelsingborg, Sweden) anesthesia. Between 10 and $20 \mu \mathrm{l}$ (in most cases $10 \mu \mathrm{l})$ of a $5 \%(\mathrm{wt} / \mathrm{vol})$ suspension of the fluorescent tracer Fast Blue (Dr. Illing, Polyloy, Gross-Umstadt, FRG) was injected with a Hamilton microsyringe at multiple sites into the ventral wall of the pyloric sphincter. Possible leakage was prevented by applying pieces of gel foam (Ferrosan, Denmark) onto the injection sites. Before the abdomen was closed, the pieces of gel foam were removed and the injection sites were inspected. Seventy-two hours later, the animals were reanesthetized and perfused through the ascending aorta with $100 \mathrm{ml}$ of Tyrode's solution followed by ice-cold $10 \%$ formalin prepared according to Pease (1962). In some cases, picric acid-containing formalin was used as described by Zamboni and de Martino (1967). The celiac-superior mesenteric ganglion was rapidly dissected and immersed in the same fixative for $90 \mathrm{~min}$ at $4^{\circ} \mathrm{C}$. The trigeminal ganglia were also dissected and served as controls for possible leakage and subsequent vascular transport (Dalsgaard, unpublished observation, 1985). The specimens were transferred to a phosphate-buffered $15 \%$ sucrose solution and stored overnight at $4^{\circ} \mathrm{C}$. They were cut on a cryostat (Dittes, Heidelberg, FRG) at $14 \mu \mathrm{m}$ section thickness, and the sections were examined in a Zeiss fluorescence microscope equipped with a dark-field oil condenser, a Schott UG 1 excitation filter, and a Zeiss 41 stop filter. After photography, the sections of the celiac-superior mesenteric ganglion were processed for indirect immunohistochemistry according to Coons and collaborators (see Coons, 1958). The sections were incubated in a humid atmosphere at $4^{\circ} \mathrm{C}$ for $24-48 \mathrm{hr}$ with antisera raised in rabbits toward SOM (dilution 1:200, 1:400; Elde et al., 1978), NPY (dilution 1:400; Lundberg et al., 1984b), VIP and polypeptide HI (PHI; dilution 1:400; Fahrenkrug and Schaffalitzky de Muckadell, 1977, 1978; Fahrenkrug and Pedersen, 1984; Fahrenkrug et al., 1985), tyrosine hydroxylase (TH; dilution 1:400; Goldstein et al., 1973; Markey et al., 1980), and dopamine $\beta$-hydroxylase (DBH; dilution 1:400; Goldstein et al., 1973). After rinsing, the sections were incubated at $37^{\circ} \mathrm{C}$ for $30 \mathrm{~min}$ with green fluorescent fluorescein isothiocyanate (FITC) or red fluorescent tetramethyl rhodamine isothiocyanate (TRITC) conjugated swine antirabbit antibodies (Dakopatts, Copenhagen, Denmark; dilution 1:10). All sera contained $0.3 \%$ Triton-X 100 (Hartman et al., 1972). To visualize the FITC-induced fluorescence, a Schott KP 500 excitation filter and an LP 520 stop filter were used. For the TRITC-induced fluorescence, a Schott BP 546 excitation filter and an LP 590 stop filter were used.

In order to show concomitant localization of 2 or more antigens, the elution-restaining technique of Tramu et al. (1978) was used. Briefly, the slides were immersed in PBS. The coverslips were then carefully removed, and, after rinsing, the sections werc exposed for 30-90 sec to a solution of acid potassium permanganate containing $2 \mathrm{ml} 2.5 \% \mathrm{KMnO}$ plus $2 \mathrm{ml} 5 \% \mathrm{H}_{2} \mathrm{SO}_{4}$ added to $50 \mathrm{ml}$ distilled water. The elution procedure was tested by incubating the sections with the secondary antibody, as above, followed by microscopic examination. If the sections were devoid of fluorescence, they were incubated with a new primary antibody followed by the secondary antibody, as above. The following sequences of primary antisera were analyzed: (1) DBH antiserum fol- lowed by SOM antiscrum; (2) TH antiserum followed by SOM antiserum, occasionally followed by NPY antiserum; (3) SOM antiserum followed by TH antiserum, occasionally followed by NPY antiserum; (4) NPY antiserum followed by TH antiserum; (5) NPY antiserum followed by SOM antiserum, occasionally followed by TH antiserum; (6) VIP/PHI antiserum followed by NPY antiserum, followed by TH antiserum; (7) VIP/PHI antiserum followed by TH antiserum, followed by NPY antiserum. As control, sections were incubated with SOM, NPY, and VIP/PHI antisera pretreated with an excess of SOM, NPY, and VIP $(10 \mathrm{nmol} / \mathrm{ml}$ diluted antisera), respectively. Normal rabbit serum served as control for TH and DBH antisera. For photography, Scopix G (Gevaert, Belgium), and Kodak Tri-X black-and-white film were used. It has recently been established in studies on a human cell line that the precursor for VIP contains a polypeptide with a marked structural homology to VIP, PHM (Itoh et al., 1983). PHM in all probability represents the human counterpart to PHI, which has been isolated from porcine intestine by Tatemoto and Mutt (1981). Since antisera to PHI and VIP in almost all cases label the same neurons (see Lundberg et al., 1984a, 1985), we will here refer to such structures as VIP/PHIimmunoreactive.

To make a quantitative evaluation, serial sections were cut through a ganglion. Three consecutive sections from 4 different levels within the ganglion were collected and incubated with antisera to SOM, NPY, and PHI, respectively, as above. The peptide-containing neurons were counted in the fluorescence microscope. The sections were then counterstained with $0.0001 \%$ ethidium bromide for $1 \mathrm{~min}$ (Schmued et al., 1982), which produces a bright-red Nissl stain when excited by green light. The sections were reexamined in the fluorescence microscope, and the total number of principal ganglion cells on each section was counted. From these results the percentage of NPY-, SOM-, and VIP/PHI-containing cells of total principal ganglion cells could be calculated.

The exact identity of the proteins and peptides analyzed in this study cannot be established with the present techniques. Therefore, we will use expressions such as "NPY-like immunoreactivity" (NPY-LI), "NPYimmunoreactive," and "NPY-positive."

\section{Results \\ Distribution of catecholamine-synthesizing enzymes and peptides}

\section{Cell bodies}

In sections incubated with $\mathrm{TH}$ and $\mathrm{DBH}$ antisera, the great majority of cells showed immunoreactivity (Fig. 1, $A-D$ ). A thorough examination of the sections revealed a small number of cells that apparently were not immunoreactive to TH. The majority of TH- and DBH-positive principal ganglion cells contained 1 or more peptides, as discussed in detail below. There was, however, a small proportion of ganglion cells that seemingly lacked any of the 4 peptides analyzed in this investigation. Small intensely fluorescent (SIF) cells were often both TH- and DBH-positive.

In sections incubated with NPY antiserum, many of the neuronal cell bodies were immunoreactive (Fig. $2 A$ ). According to a quantitative evaluation, about $65 \%$ of the principal ganglion cells contained NPY-LI. Single SIF cells were NPY-immunoreactive (Fig. $2 A$ ). Sections incubated with SOM antiserum also contained many labeled cells (Fig. $2 B$ ), but they usually wcre less prevalent than the NPY cells, representing approximately $25 \%$ of all the ganglion cells. No SOM-positive SIF cells were observed (Fig. $2 B$ ). Examination of consecutive sections incubated with SOM and NPY antisera revealed that the SOM- and NPY-positive neurons had a complementary distribution in the ganglion ( $c f$. Fig. 2, $A$ and $B$ ). In areas where NPY neurons predominated (Fig. $2 A$ ), only a few cells containing SOM-LI were observed (Fig. $2 B$ ). In other areas, SOM-containing cell bodies predominated (Fig. $2 B$ ) and outnumbered the neurons with NPY-LI (Fig. 2A). These 2 principal ganglion cell populations had a distinct topographic localization within the ganglion - the NPY cells being present bilaterally in the posterior, superior parts, i.e., the celiac poles, and the SOM cells in the anterior, inferior part, i.e., superior mesenteric pole (see Fig. 8). 

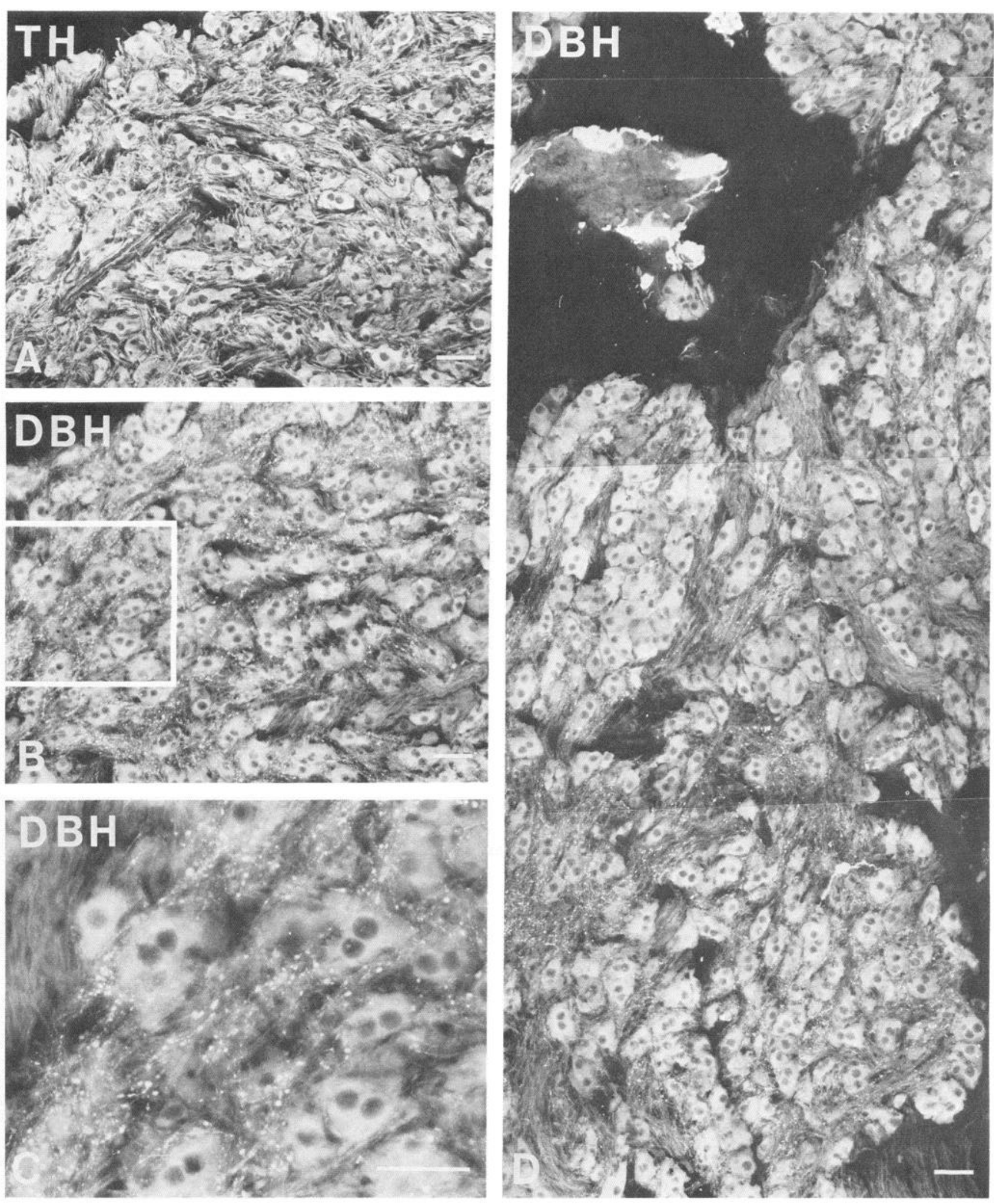

Figure 1. Immunofluorescence micrographs ( $D$ is a montage) of the celiac-superior mesenteric ganglion after incubation with antisera to TH $(A)$ and DBH $(B-D)$. Section incubated with antisera to DBH is semiconsecutive to the sections shown in Figure $2, A$ and $B$. Virtually all cell bodies are TH-positive $(A)$ and DBH-positive $(C-D)$. A network of DBH-positive varicose nerve fibers can be seen $(B)$. A similar varicose network cannot be seen in a corresponding region incubated with TH antiserum $(A)$. In $C$ the DBH-positive varicose nerve fibers from the framed region in $B$ are shown at higher magnification. The DBH-positive varicose fiber network can be seen in the lower part of the montage in $D$. By comparing the semiconsecutive sections (Fig. 2, A,B), it could be established that the varicose fiber network is found in a region where the SOM cells predominate. Bars, $50 \mu \mathrm{m}$. 

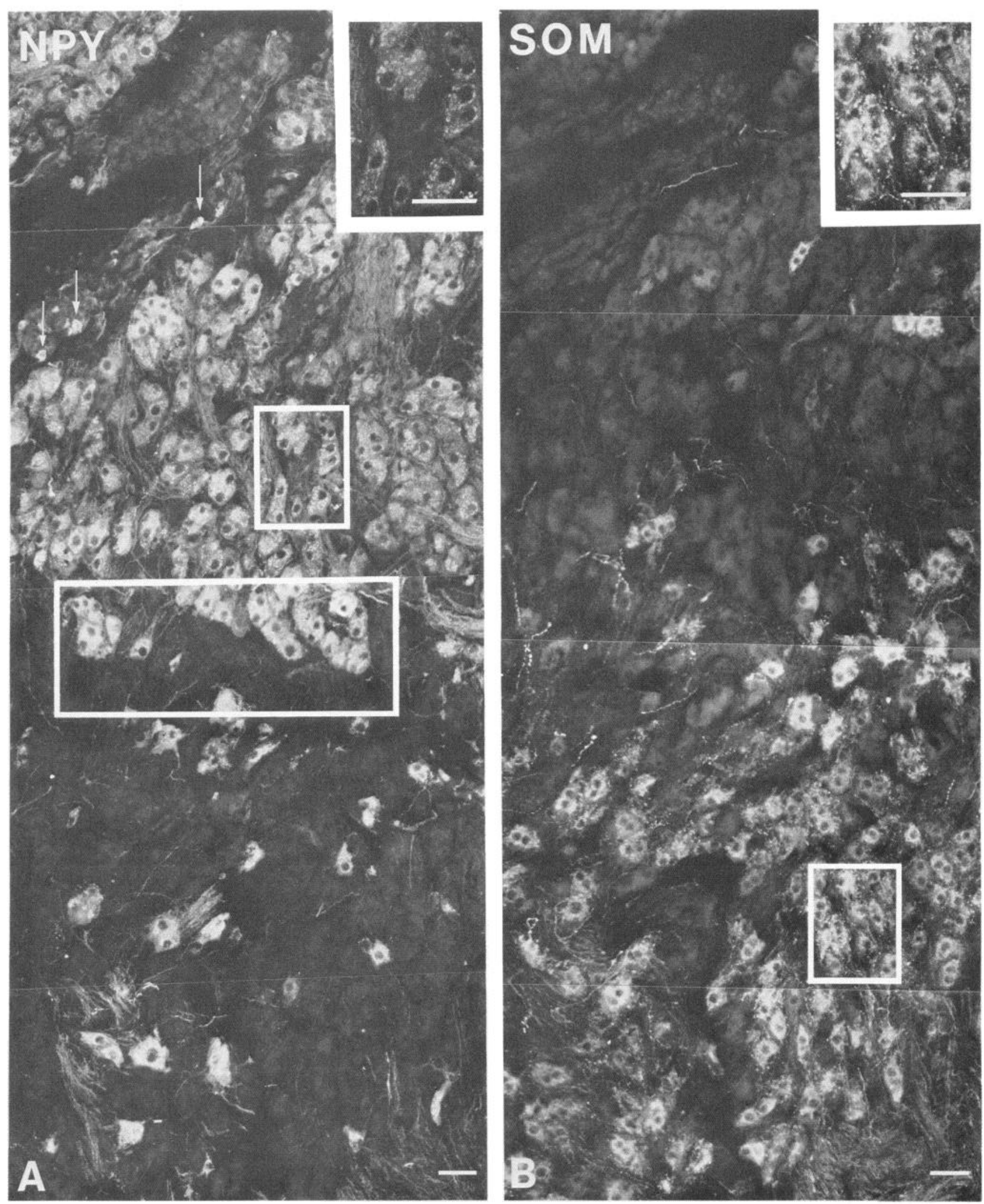

Figure 2. Immunofluorescence micrographs (montages) of 2 consecutive sections of the celiac-superior mesenteric ganglion of the guinea pig after incubation with antisera to NPY $(A)$ and SOM $(B)$. The NPY- and SOM-positive cells have a complementary distribution in the ganglion. Arrows point to single NPY-immunoreactive SIF cells $(A)$. Higher magnification images of the framed region (lower rectangle) in $A$ are shown in Figure 4. Higher magnification images of the upper rectangle in $A$ and the framed region in $B$ are inset into the right upper corners. Varicose nerve fibers form basketlike structures that surround the SOM-containing perikarya and form a dense network of SOM-immunoreactive nerve terminals $(B)$. A similar dense network of NPY-immunoreactive nerve terminals cannot be seen $(A)$. Bars, $50 \mu \mathrm{m}$. 


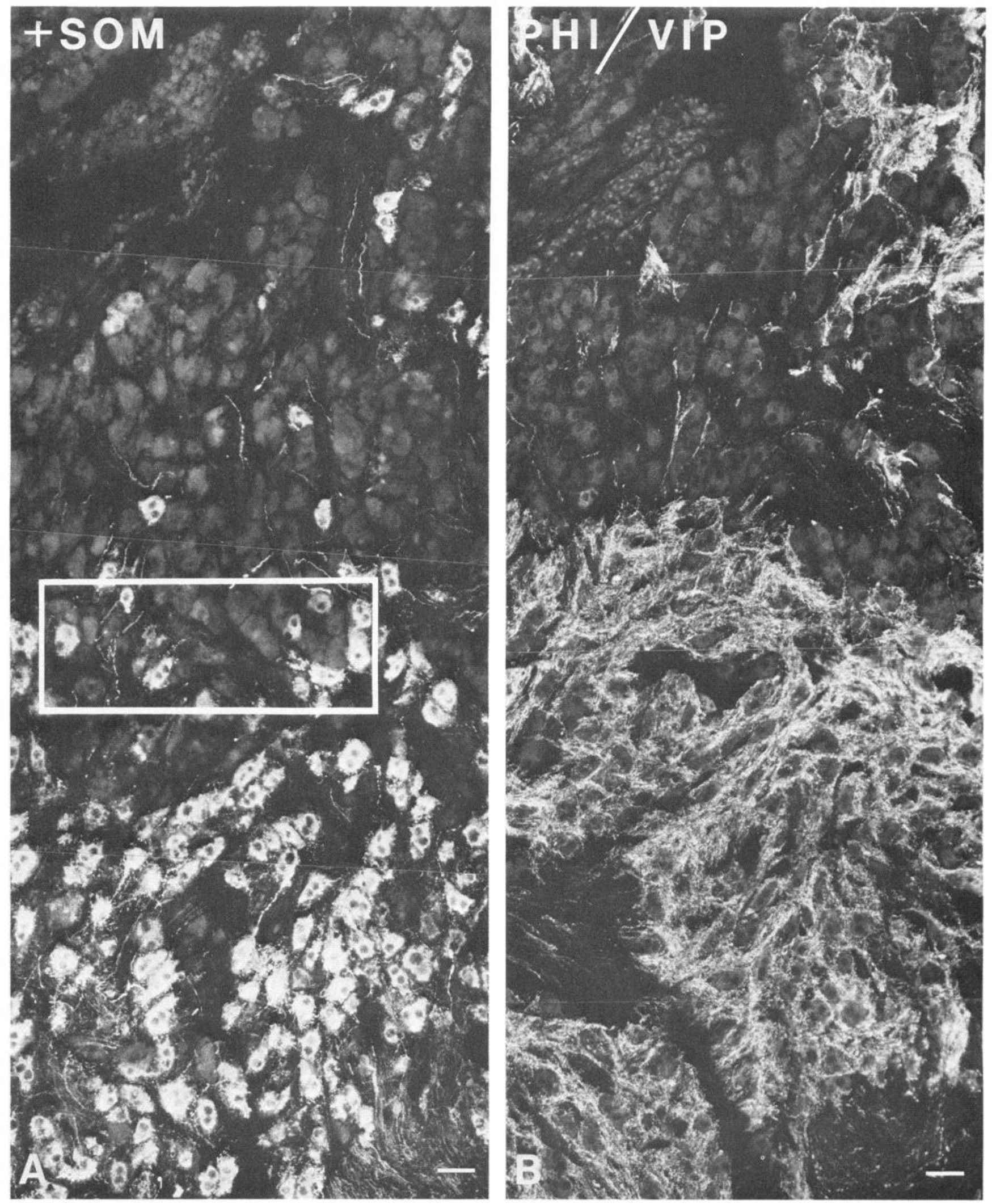

Figure 3. A, Immunofluorescence micrograph (montage) showing the same section as in Figure $2 A$ after an elution and restaining with antibodies to SOM. In general, NPY-positive cells are SOM-negative and vice versa. Occasional cells contain both NPY- and SOM-LI. These cells can be seen in the framed regions in Figures $2 A$ (lower rectangle) and $3 A$, which are shown at higher magnification in Figure $4, A$ and $B$, respectively. Bar, $50 \mu \mathrm{m}$. $B$, Immunofluorescence micrograph (montage) of a section of the celiac-superior mesenteric ganglion after incubation with antiserum to PHI. A very dense network of PHI/VIP-positive fibers can be seen. Analysis of the consecutive sections incubated with antisera to NPY (Fig. $2 A$ ) and SOM (Fig. $2 B$ ) revealed that the PHI/VIP fibers are generally confined to SOM-cell areas. Bar, $50 \mu \mathrm{m}$. 
In elution-restaining experiments, it could be established that, in general, NPY-positive cells were SOM-negative and vice versa (Figs. $2 A ; 3 A ; 4, A, B$ ). However, occasional cells contained both NPY- and SOM-LI (Figs. $2 A ; 3 A ; 4, A, B$ ). After a second elution and restaining with TH antiserum, it could be confirmed that the vast majority of NPY- and SOM-positive cells also contained this catecholamine-synthesizing enzyme (Fig. $4 \mathrm{C}$ ). A small number of principal ganglion cells containing both NPYand SOM-LI were, however, apparently TH-negative (Fig. 4, $A-C$ ).

A third population of principal ganglion cells was also encountered reacting with both VIP and PHI antiserum (Fig. 5, $A$ and $D$ ). Their number was low compared with the SOM- and NPY-immunoreactive cell populations, comprising less than $1 \%$ of the principal ganglion cells. They were mainly located in the celiac poles (see Fig. 8). Analysis of thin adjacent sections revealed that the same cells were both VIP- and PHI-immunoreactive. Two populations could be distinguished with regard to size, single large cells with a diameter of about $50 \mu \mathrm{m}$ (Fig. $5 A$ ), and a larger number of small cells with a diameter of about $25 \mu \mathrm{m}$ (Fig. $5 D$ ). In restaining experiments it could be established that the population of small VIP/PHI-positive cells also containcd NPY-LI (Fig. 5E). These cclls scemed to lack TH-LI (Fig. $5 F$ ). Some of the larger cells seemed to contain immunoreactivity both to the enzyme and the 2 peptides, VIP/PHI plus NPY (Fig. 5, $B, C$ ). The SIF cells did not appear VIP/PHIimmunoreactive (Fig. $3 B$ ).

\section{Fiber networks}

A dense network of SOM-immunoreactive, varicose nerve fibers was observed in the part of the ganglion containing SOM-immunoreactive cells, forming basketlike structures around the SOM-containing perikarya, as well as running between the ganglion cells (Fig. $2 B$ ). Single SOM-positive fibers were also encountered among the NPY-containing cells. It was not possible to establish definitely whether the varicose SOM fibers originated from SOM-containing principal ganglion cells, being either axons or dendrites, possibly partly accessory dendrites, or originated extrinsically. NPY-positive fibers were seen either in bundles or as single fibers, mainly around the NPY-positive cells and in lower numbers among the SOM-positive cells (Fig. 2A). However, they did not exhibit the characteristic, distinctly varicose network formed by SOM terminals, either in the NPYor in the SOM-dominated part of the ganglion.

In sections incubated with $\mathrm{DBH}$ antiserum, there was a network of varicose fibers that was fairly similar to the one seen with SOM antiserum (Fig. 1, $B-D$ ). By comparing consecutive sections it could be established that this fiber network was confined to the region predominated by SOM-containing neurons. Elution-restaining experiments revealed a few cases in which these 2 markers (DBH and SOM) occurred in the same fibers (Fig. 4, D, E). A corresponding varicose fiber network could not be found in sections incubated with $\mathrm{TH}$ antiserum (Fig. 1A). Dense networks of TH-positive fibers were, however, also seen, but they had a smooth appearance without apparent varicosities and were distributed fairly evenly within the ganglion. TH-, DBH-, NPY-, and SOM-positive fibers were also seen in intraganglionic nerve bundles, as well as in small nerves leaving the ganglion.

In sections incubated with antisera raised toward VIP or PHI, a very dense network of VIP/PHI-positive fibers was observed (Fig. 3B). Analysis of consecutive sections showed that the VIP/ PHI-positive fibers were generally confined to areas where SOMcontaining cells predominated ( $c f$. Figs. $3 B$ and $2 B$ ), and only a few fibers were seen where the NPY- and the VIP/PHI-immunoreactive cell bodies were located.

\section{Retrograde tracing experiments}

Seventy-two hours after injection of Fast Blue into the pyloric sphincter, retrogradely labeled, bright-blue fluorescent neuronal cell bodies were observed in the celiac-superior mesenteric ganglion (Figs. 6, $A-C$ and $7 A$ ). The labeled cell bodies were found in all parts of the ganglion, with a possible predominance in the celiac poles. No clearly labeled cells were found in the trigeminal ganglia.

Examination of micrographs taken from sections containing Fast Blue-labeled cell bodies, subsequently stained for $\mathrm{TH}$, showed that the overwhelming majority of cell bodies that contained the fluorescent tracer also contained the enzyme. Comparison of micrographs taken from the same sections analyzed consecutively for retrogradely transported Fast Blue and NPYand SOM-LI showed neurons containing both the fluorescent tracer and immunoreactivity to NPY (Figs. $6, D-F ; 7 B$ ) or SOM (Fig. 7C). So far, no cell bodies have been observed to contain all 3 markers (Fast Blue, NPY, and SOM). The Fast Blue-labeled cells containing NPY-LI clearly outnumbered the Fast Bluelabeled cells containing SOM-LI. In addition, there were cell bodies that contained only the fluorescent tracer or only 1 of the peptides. Elution-restaining experiments established that neurons containing both Fast Blue and a peptide were also immunoreactive to TH (Figs. 6, $G-I$ and $7 D$ ). Occasional cells that contained both Fast Blue and NPY-LI and that seemed to lack TH-LI were, however, also observed (Fig. 6, $C, F$, and $I$ ). Furthermore, it could bc established that some Fast Blue-labeled cells containing TH-LI seemed to lack immunoreactivity toward SOM and NPY (Fig. 7, $A-D$ ).

After incubation with control sera, none of the immunoreactive staining patterns described above could be observed.

\section{Discussion}

\section{Transmitter enzymes and peptides in cell bodies and fibers}

The present results confirm and extend earlier information on the localization and distribution of various peptides within the principal ganglion and SIF cells of the celiac-superior mesenteric ganglion. A summary of the results obtained is presented in Figure 8. Thus, SOM-positive principal ganglion cells were first demonstrated in high numbers (Hökfelt et al., 1977a) and, subsequently, it was recognized that a different population of neurons contains a peptide that can be demonstrated with antiserum raised to avian pancreatic polypeptide (APP) (Lundberg et al., 1982a). Subsequent analyses have revealed that this peptide in all probability represents an NPY-like peptide (Lundberg et al., 1983, 1984b). The present findings clearly demonstrate that the 2 peptides are in separate cell populations that occupy specific domains within the ganglion (Fig. 8). Thus, the SOM cells are mainly found in the anterior-inferior part of the ganglion, representing the superior mesenteric pole, whereas the NPY cells are found bilaterally in the celiac poles, which occupy the posterior-superior parts of the ganglion. A similar regional preponderance of the SOM-positive cells in the anterior-inferior part of the ganglion was described in the earlier paper by Hökfelt et al. (1977a). A certain degree of overlap and intermingling exists, and there are, in fact, a few cells that are immunoreactive to both peptides. The present quantitative evaluation demonstrates that NPY-positive cells are most numerous, representing about two-thirds of all ganglion cells, whereas the SOM cells make up about $25 \%$.

A third population of ganglion cells was observed, characterized by its content of a VIP-like peptide, in agreement with earlier studies (Hökfelt et al., 1977b). This cell population also contains a second peptide, peptide histidine isoleucine ( $\mathrm{PHI}$, which has recently been discovered by Tatemoto and Mutt (1980, 

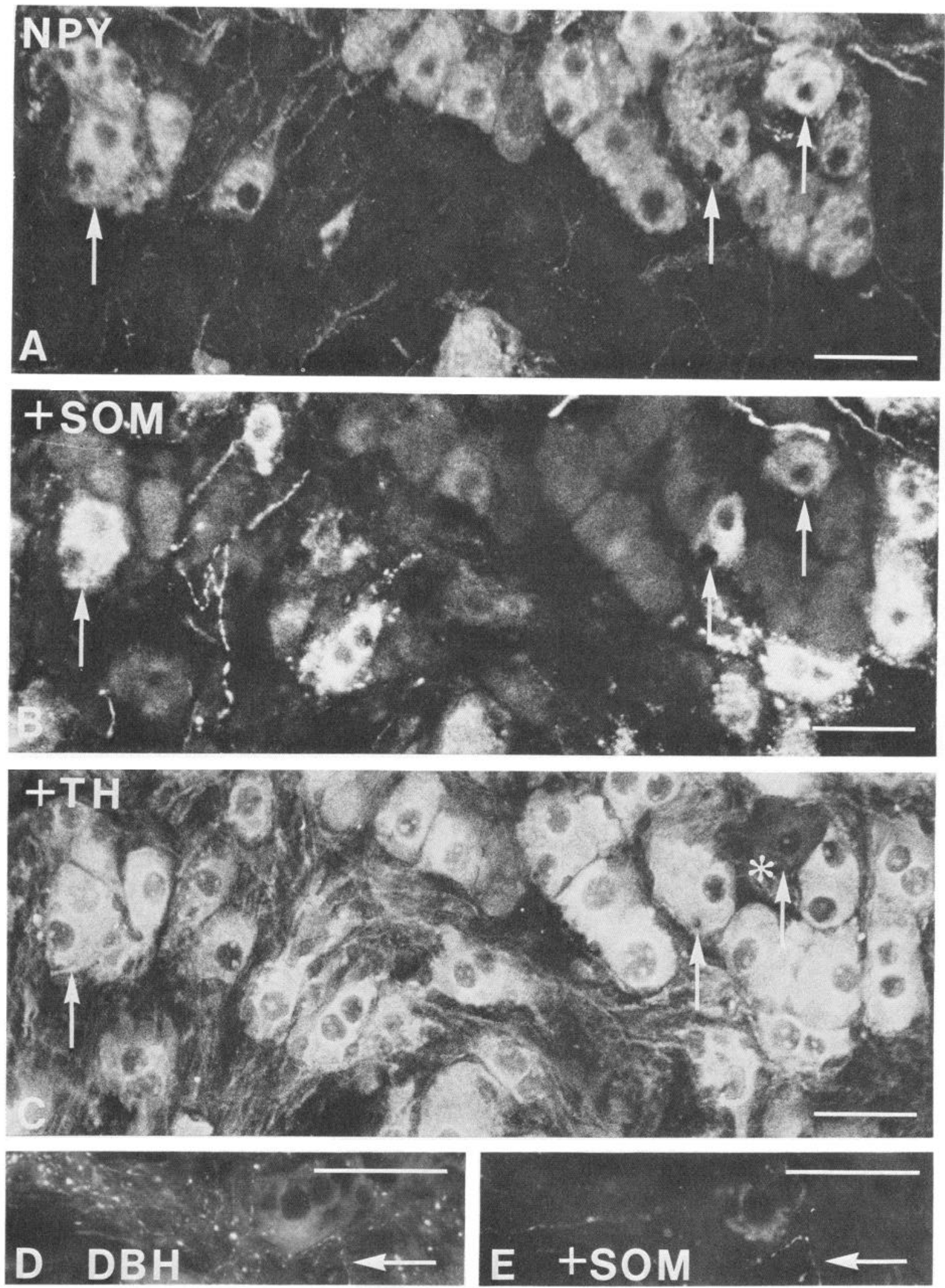

Figure 4. $A-C$, Higher magnification of the framed regions in Figures $2 A$ and $3 A$. Arrows point to NPY-positive neurons $(A)$ that also contain SOM-LI $(B)$. After a second elution-restaining experiment using antiserum to TH $(C)$, it could be established that 1 of these cells apparently lacked TH-LI (asterisks). Bars, $50 \mu \mathrm{m}$. $D$ and $E$, Immunofluorescence micrographs of a section of the celiac-superior mesenteric ganglion after incubation with antiserum to $\mathrm{DBH}(D)$. After elution with acid $\mathrm{KMnO}_{4}$, the section was incubated with antiserum to SOM $(E)$. Arrows, Fiber containing both DBH- and SOM-LI. Bars, $50 \mu \mathrm{m}$. 

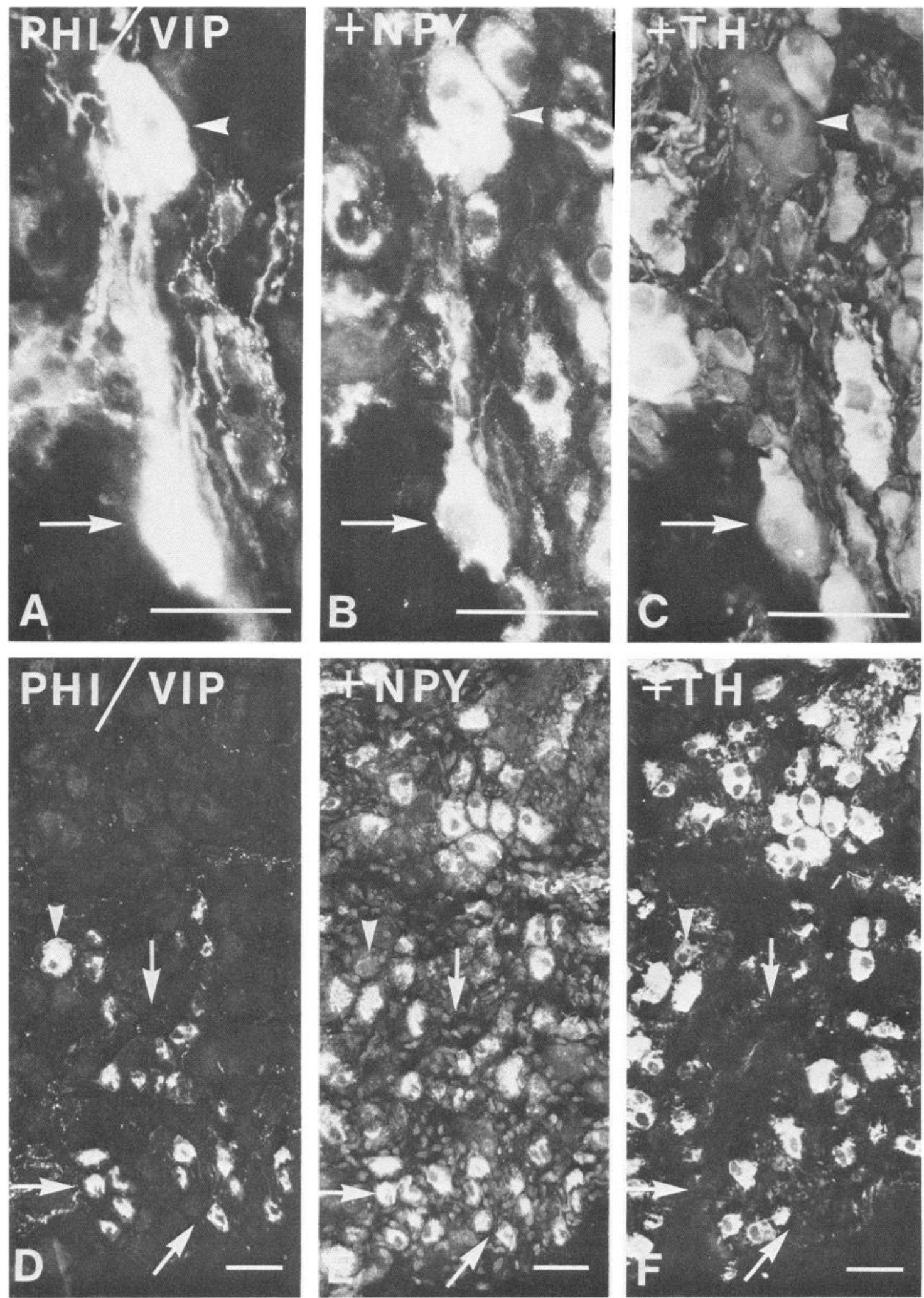

Figure 5. Immunofluorescence micrographs of 2 sections of the celiac-superior mesenteric ganglion after incubation with antisera to PHI $(A, D)$, NPY $(B, E)$, and TH $(C, F)$. Elution-restaining technique of Tramu et al. (1978) was used. In $A-C$, arrows point to a larger cell containing immunoreactivity to PHI/VIP, NPY, and TH. Arrowheads point to a larger PHI/VIP-positive neuron that seems to contain NPY-LI but not THLI. In $D-F$, arrows point to 3 groups of smaller PHI/VIP-positive neurons $(D)$ that contain NPY-LI $(E)$ but seem to lack TH-LI $(F)$. Arrowheads point to a larger cell that contains PHI/VIP-LI $(D)$ and TH-LI $(F)$. This neuron seems to lack NPY-LI $(E)$. Bars, $50 \mu \mathrm{m}$. 

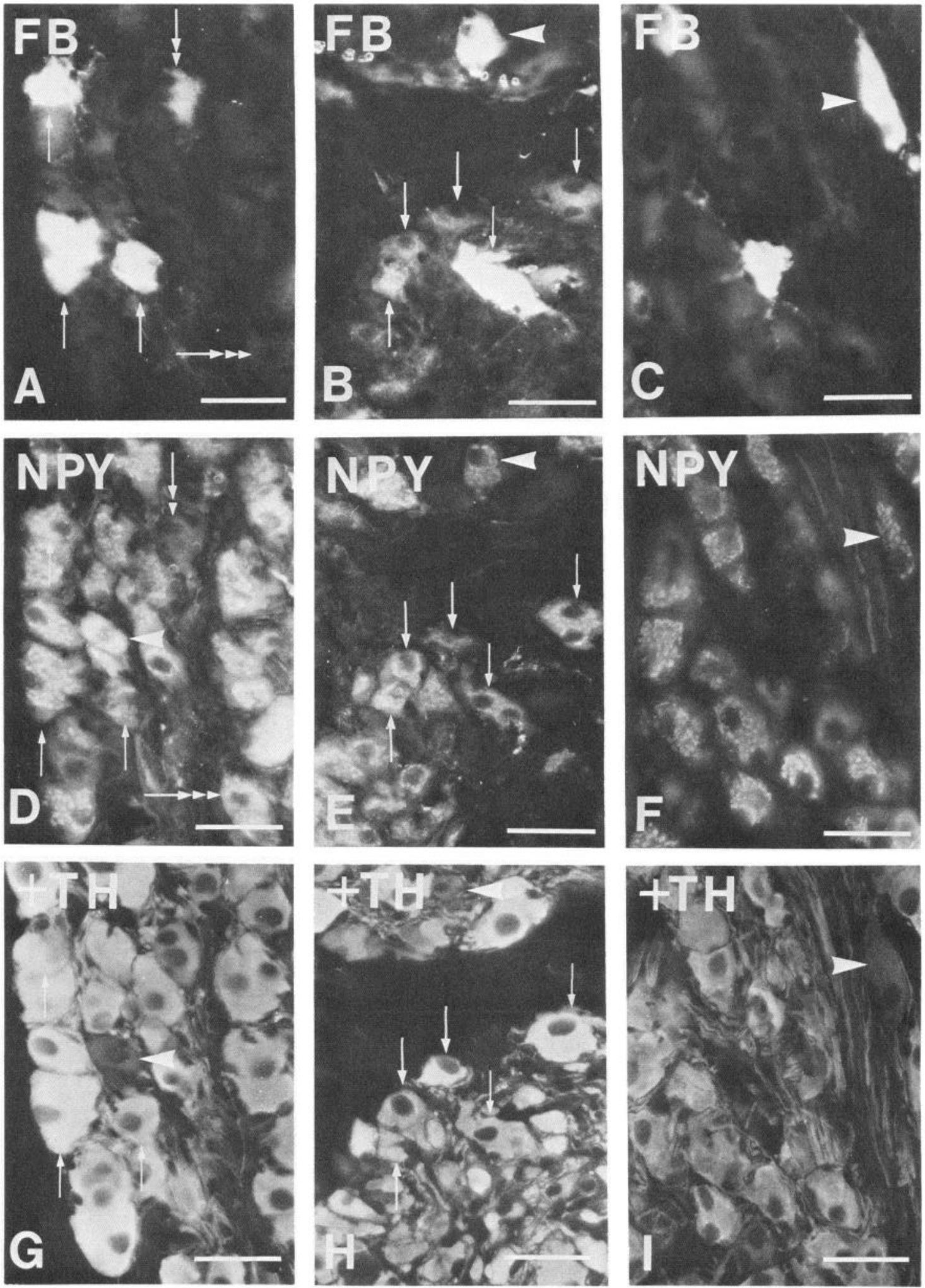

Figure 6. Fluorescence $(A-C)$ and immunofluorescence $(D-I)$ micrographs of the celiac-superior mesenteric ganglion after injection of Fast Blue $(F B)(A-C)$ into the pyloric sphincter and subsequent processing for immunohistochemistry using antisera to NPY $(D-F)$ and TH $(G-I)$. Micrographs $A, D, G ; B, E . H$; and $C, F, I$ taken from 3 different sections. The elution-restaining technique of Tramu et al. (1978) was used. Arrows point to cells containing all 3 markers-FB, NPY, and TH $(A-I)$. Arrowheads point to NPY-positive cells $(D-F)$ that seem to lack or have very low levels of TH-LI $(G-I)$. Two of these cells contain FB $(B, C)$, indicating that they project to the pylorus. Double arrows point to a FB-containing cell devoid of NPY-LI; triple arrows point to a NPY-positive cell that lacks the dye. Bars, $50 \mu \mathrm{m}$. 
Figure 7. Fluorescence $(A)$ and immunofluorescence $(B-D)$ micrographs of a section of the celiac-superior mesenteric ganglion after injection of Fast Blue $(A)$ into the pyloric sphincter and subsequent processing for immunohistochemistry using antisera in the sequence SOM $(C)$, TH $(D)$, and NPY $(B)$. The elution-restaining technique of Tramu et al. (1978) was used. Arrows point to 3 cells that contain the dye $(A)$, one of which is SOM-positive $(C$, asterisk) and a second one that is NPYpositive $(B$, asterisk). All 3 cells contain TH-LI $(D)$. One of these cells, which also contains the dye, lacks peptide immunoreactivity ( $c f . A-D)$. Bars, $50 \mu \mathrm{m}$.
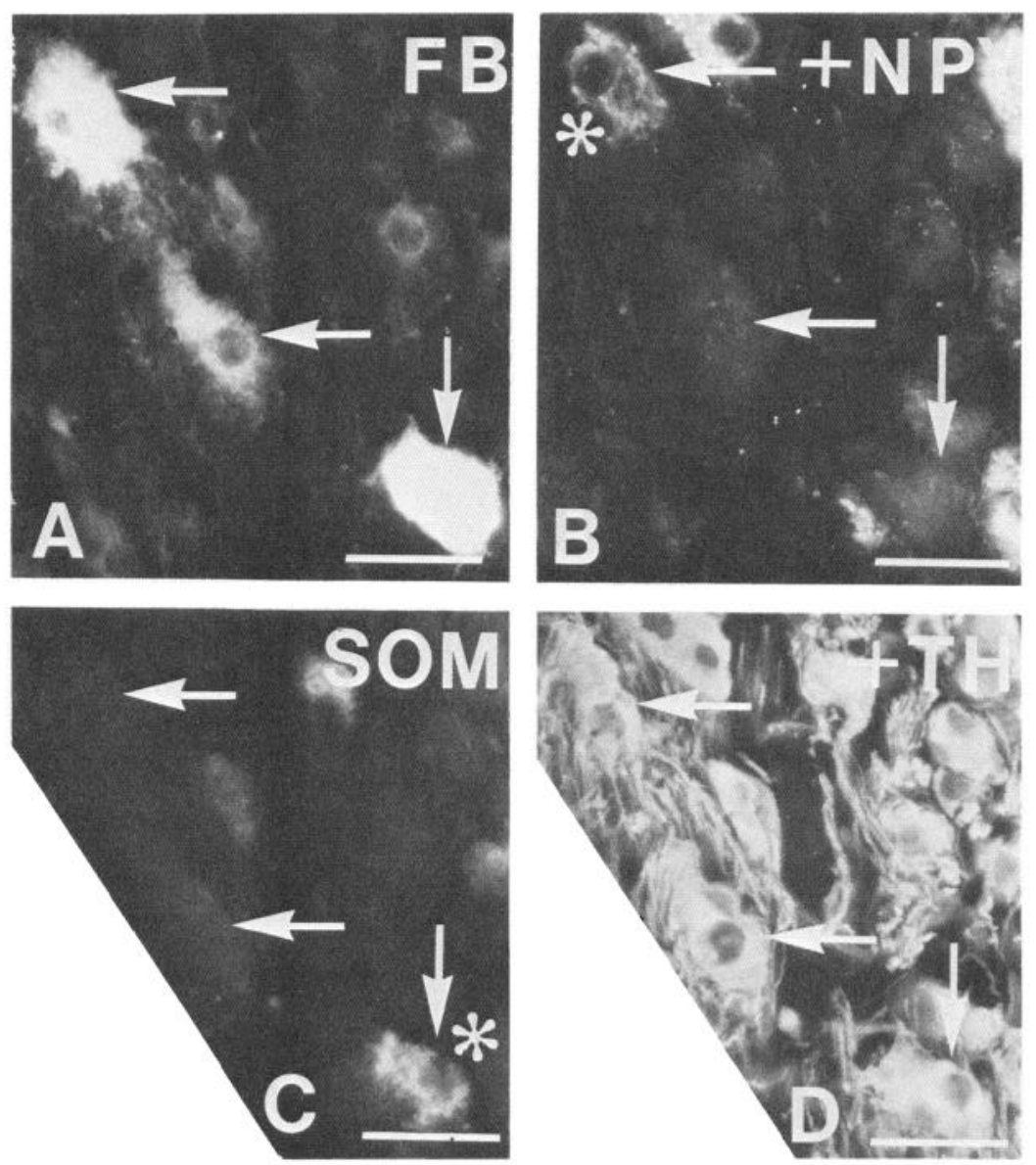

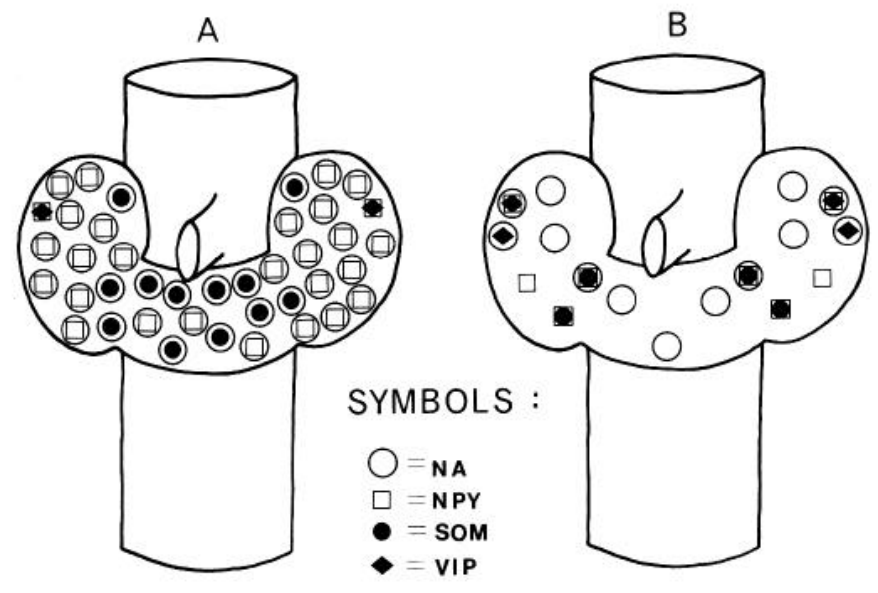

CELL TYPES:
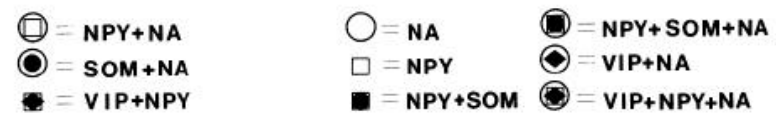

Figure 8. Schematic drawing illustrating the celiac-superior mesenteric ganglion and the various cell types found in this study. $A$, Topographic localization of the 3 main populations of peptidergic cells in the ganglion. For each of the 3 peptides, the most frequent coexistence situation is indicated. $B$, Other, more infrequently occurring cell types defined by their transmitter content as found in this study. The drawings give only a rough quantitative account of the different cell types.
1981). Subsequent studies using recombinant DNA technology have demonstrated that PHI is part of the precursor for VIP, which thus contains a copy of both VIP and PHI (Itoh et al., 1983). These findings are in complete agreement with the present demonstration of PHI and VIP in the same prevertebral ganglion cells, as well as with other immunohistochemical studies demonstrating colocalization of these 2 peptides (Bishop et al., 1984; Fahrenkrug et al., 1985; Lundberg et al., 1984a; Yanaihara et al., 1983). Two populations of VIP/PHI neurons could be distinguished by their size: small cells, which were more numerous, and single large ones. Also, the VIP/PHI neurons occupied a distinct domain in the ganglion within the celiac poles, intermingling with the NPY-immunoreactive cell bodies (Fig. 8).

The vast majority of the NPY- and SOM-positive cells contained TH- and DBH-LI, suggesting that they are noradrenergic. A few NPY-immunoreactive cells did, however, lack $\mathrm{TH}$, indicating that a small population of principal ganglion cells is nonadrenergic. The occurrence of non-adrenergic NPY-positive autonomic neurons is discussed further below. The majority of the VIP/PHI-positive cells were also TH-negative, and these non-adrenergic cells were of the small type, whereas single large VIP/PHI-positive cells also contained TH-LI. Whether these differences reflect the actual situation or whether an insensitivity in our immunohistochemical technique is involved is not known.

The present study confirms earlier findings of a lack of SOMand VIP-LI in SIF cells. It adds the information that a few SIF cells are NPY-immunoreactive.

The present findings demonstrate differences in appearances of SOM- and NPY-immunoreactive fibers. NPY-immunoreactive fibers have a smooth appearance and can be found in all parts of the ganglion. They are only weakly immunoreactive 
and could represent axonal processes and fiber bundles. Similar SOM-positive fibers can also be seen, but, in addition, there is a distinct and fairly dense network of strongly fluorescent, varicose SOM-positive fibers, in most cases closely surrounding SOM-positive cells but also found in the fiber strands in between the ganglion cells. The nature of these fibers is uncertain. They may represent dendritic processes emanating from the ganglionic cell bodies or collaterals from the axons leaving the ganglion cells. Alternatively, they may have an extrinsic origin. Experiments are now in progress to try to define these fibers in more detail. Intcrestingly, a fiber network of a similar morphology and apparent density is seen after incubation with DBH antiserum. Surprisingly, this DBH-positive network was mainly confined to the SOM-dominated part of the ganglion, thus showing a close overlap with the varicose SOM fibers. We attempted to establish or exclude identity between these 2 fiber networks by carrying out restaining experiments. In a few cases, DBHand SOM-LI could be seen in the same fibers, but difficulties in restaining such thin fibers precluded a conclusive answer.

If the SOM-positive varicose network emanates from the SOM ganglion cells, these cells would have a distinctly different morphology compared to the NPY-immunoreactive neurons, which apparently lack processes of this type. Whether this distinct difference between NPY and SOM neurons is real or represents an artifact related to the immunohistochemical technique is at present being analyzed by studies at the EM level. Incubation with $\mathrm{TH}$ antiserum did not reveal a fiber network corresponding to the DBH-positive varicosities. Instead, there was a dense network of smooth TH-positive fibers. This may be because the enzyme TH is cytoplasmic and fills out the entire axon, whereas $\mathrm{DBH}$ is largely membrane-bound (vesicles) and therefore stains varicosities preferentially.

\section{Projections to the pylorus}

The present investigation gives strong evidence for a projection to the guinea pig pylorus from the celiac-superior mesenteric ganglion, in agreement with an earlier study by Elfvin and Lindh (1982). Here, we describe at least 4 subpopulations of postganglionic sympathetic neurons in the celiac-superior mesenteric ganglion projecting to the pylorus. These are neurons apparently containing only TH-LI, neurons containing immunoreactivity to both TH and NPY, neurons immunoreactive to both TH and SOM, and neurons containing immunoreactivity only to NPY. It should be pointed out that the definition of 4 categories is based on presence or absence of the enzyme TH and 2 peptides as revealed with immunohistochemistry. It is quite possible that our technique is not sensitive enough to reveal low levels of these compounds, and the present subdivision may therefore have to be revised in the future.

The description of these pathways is based on a technique that involves a combination of fluorescent retrograde tracing with immunohistochemistry (Hökfelt et al., 1983; Skirboll et al., 1984). The method has previously been used in our laboratory in, for example, studies of peptidergic pathways projecting to the inferior mesenteric ganglion in the guinea pig (Dalsgaard et al., 1982a, b) and of the origin of the sensory substance $P$ innervation of the pylorus (Lindh et al., 1983). Since the fluorescent tracer Fast Blue is not stable during the immunocytochemical procedures, there is a risk that the tracer diffuses out of the cells during the incubation period. Therefore, the labeled cells are photographed before the sections are incubated with the different primary antisera. Fast Blue has a tendency to "shine through" the FITC filters, and we have therefore used a TRITC conjugated secondary antibody. Cells retrogradely labeled with Fast Blue were found in all parts of the ganglion, but they seemed to be more prevalent in the celiac poles, suggesting a somatotopic organization within the ganglion.

Since peripherally injected fluorescent dyes can reach gangli- onic cell bodies via the vascular system (Dalsgaard, unpublished observations), we also analyzed possible labeling of cell bodies in the trigeminal ganglion. Since no Fast Blue cell bodies were observed in this ganglion in our study, it seems likely that the Fast Blue-positive cells in the celiac-superior mesenteric ganglion have been labeled by retrograde axonal transport and not by blood-borne dye.

The retrogradely labeled cells were practically all TH-containing, which shows that the pylorus receives a heavy NA projection from the ganglion. In earlier studies, it has been shown by mcans of the formaldehydc-induced (Falck-Hillarp) fluorescence technique that the pyloric sphincter muscles of the guinea pig have a dense network of NA nerve terminals (Costa and Gabella, 1971; Gabella, 1979). The NA innervation of the guinea pig pylorus has also been demonstrated with immunohistochemical techniques with antisera raised toward DBH (Schultzberg et al., 1980). The adrenergic innervation to the pylorus exerts a contractile action on the sphincter, demonstrated by splanchnic nerve stimulation and local intraarterial infusion of noradrenaline (Edin et al., 1979).

A substantial number of the Fast Blue-labeled cells containing TH were also immunoreactive for SOM and NPY. The present observations show that some of these cells with multiple messengers also project to the guinea pig pylorus. The results of the present study agree with the findings of Furness et al. (1983) and Costa and Furness (1984), who, using a combination of immunohistochemistry and nerve lesion techniques, demonstrated a projection to the guinea pig small intestine of NA neurons containing SOM- or NPY-LI (see below).

There were more Fast Blue-labeled cells immunoreactive to NPY than to SOM in the ganglion, which, in part, may reflect the higher proportion of NPY- as compared to SOM-immunoreactive principal ganglion cells and the fact that most retrogradely labeled cells were found in the celiac poles, i.e., the region containing predominantly NPY-positive ganglion cells. This indicates that the pyloric region receives a somewhat more prominent projection of NA/NPY neurons than of NA/SOM neurons. Two more subgroups of neurons projecting to the guinea pig pylorus comprise cells containing only a catecholamine and a small group of cells that appear to contain only NPY-LI. In this context it should be mentioned that Hassal and Burnstock (1984) and Dalsgaard et al. (1985) recently provided evidence for NPY-immunoreactive cell bodies in atrial ganglia that seemed to lack TH-LI. Such NPY-positive, apparently noncatecholaminergic neurons have also been observed in the rat vas deferens (Fried et al., 1985) and in the human fallopian tube (Samuelson and Dalsgaard, 1985). The latter results must be interpreted with caution, since they may reflect a difficulty in detecting the enzyme, but the lissue culture studies of Hassal and Burnstock (1984) strongly support the presence of noncatecholaminergic NPY neurons. Furthermore, it is known that immunoreactive NPY cell bodies that are apparently non-NA occur in the enteric ganglia in the gastrointestinal tract of the guinea pig and the rat (Furness et al., 1983; Sundler et al., 1983).

The exact target areas in the pylorus of the subclasses of neurons demonstrated in the present study are unknown and can only be clearly determined by a systematic analysis of the terminal network of the nerves in combination with denervation procedures.

\section{Functional aspects}

Although the classification of the functional roles of the various nerves projecting to the guinea pig pylorus has to await further study, some comparison can be made with earlier studies in which the specific functions of the NA/NPY, NA/SOM, and NA neurons have been investigated. Thus, in their elegant experiments, Furness et al. (1983) and Costa and Furness (1984) showed that the different subgroups of NA neurons in the celiac- 
superior mesenteric ganglion of the guinea pig seem to supply separate tissue components in the wall of the small intestine. The major targets for the NA/NPY neurons were the intestinal blood vessels, whereas the NA/SOM neurons seemed to innervate the submucosal ganglia and the mucosa. The NA nerves lacking NPY - and SOM-LI projected to the myenteric ganglia. The different target areas for the neurochemical groups of NA nerves suggest that these groups also have different functional properties. The NA/NPY neurons would be involved in regulation of intestinal blood flow, the NA/SOM neurons in control of mucosal function, and the NA nerves lacking NPY- and SOM-LI primarily in regulation of intestinal motility. A preferential role of NA sympathetic neurons containing NPY-LI in control of blood flow has also been suggested in several studies by Lundberg et al. (1982b, 1985).

The analysis of the distribution patterns of peptide terminals in the celiac-superior mesenteric ganglion confirms earlier findings of a dense, heterogeneously distributed VIP-immunoreactive fiber network (Hökfelt et al., 1977b). The present results confirm the previous demonstration that these terminals mainly innervate NA ccll bodics containing SOM-LI (Lundberg et al., 1982a). These VIP fibers presumably originate in the intestinal wall, as has been shown for the guinea pig inferior mesenteric ganglion (Dalsgaard et al., 1983). The results suggest chemical coding within the celiac-superior mesenteric ganglion with regard to content of messenger molecules both in the principal ganglion cells and in fibers of extrinsic origin. The strict organizational principles may point to a possible functional differentiation on the basis of chemical specificity. In this respect, the studies of Costa and Furness (Costa and Furness, 1984; Furness et al., 1983) discussed above are interesting. This would suggest that VIP-containing afferents are mainly important in controling mucosal function and may not participate in regulating blood flow (see above). Related studies show that several other peptide-containing afferents to the celiac-superior mesenteric ganglion - including dynorphin-, cholecystokinin-, and bombesin-immunoreactive fibers-have a distribution parallel to that of the VIP/PHI-immunoreactive fibers (unpublished observations). Since they may all originate in the gastrointestinal wall, they may participate in the reflex arc between intestine and prevertebral ganglia. In contrast, strongly enkephalin- as well as choline acetyltransferase-immunoreactive fibers also innervate the NPY domains of the ganglia, and these fibers may have a central origin. Such findings suggest that control of intestinal blood flow (via NA/NPY prevertebral neurons) is mainly exerted via the CNS. Only further experiments can verify this hypothesis.

\section{References}

Bishop, A. E., J. M. Polak, Y. Yangou, N. D. Christofides, and S. R. Bloom (1984) The distribution of PHI and VIP in porcine gut and their co-localisation to a proportion of intrinsic ganglion cells. Peptides 5: 255-259.

Brazeau, P., W. Vale, R. Burgus, N. Ling, M. Butcher, J. Rivier, and R. Guillemin (1973) Hypothalamic polypeptide that inhibits the secretion of immunoreactive pituitary growth hormone. Science 179 : $77-79$.

Coons, A. H. (1958) Fluorescent antibody methods. In General $\mathrm{Cy}$ tochemical Methods, J. F. Danielli, ed., pp. 399-422, Academic, New York.

Costa, M., and J. B. Furness (1984) Somatostatin is present in a subpopulation of noradrenergic nerve fibres supplying the intestine. Neuroscience 13: 911-919.

Costa, M., and G. Gabella (1971) Adrenergic innervation of the alimentary canal. Z. Zellforsch. 122: 357-377.

Dalsgaard, C.-J., A. Franco-Cereceda, A. Saria, J. M. Lundberg, E. Theodorsson-Norheim, and T. Hökfelt (1986) Distribution and or- igin of substance $\mathrm{P}$ - and neuropeptide $\mathrm{Y}$-immunoreactive nerves in the guinea pig heart. Cell Tissue Res. 243: 477-485.

Dalsgaard, C.-J., T. Hökfelt, L.-G. Elfvin, L. Skirboll, and P. Emson (1982a) Substance P-containing primary sensory neurons projecting to the inferior mesenteric ganglion: Evidence from combined retrograde tracing and immunohistochemistry. Neuroscience 7:647-654.

Dalsgaard, C.-J., T. Hökfelt, L.-G. Elfvin, and L. Terenius (1982b) Enkephalin-containing sympathetic preganglionic neurons projecting to the inferior mesenteric ganglion: Evidence from combined retrograde tracing and immunohistochemistry. Neuroscience 7: 2039-2050.

Dalsgaard, C.-J., T. Hökfelt, M. Schultzberg, J. M. Lundberg, L. Terenius, G. J. Dockray, and M. Goldstein (1983) Origin of peptide containing fibers in the inferior mesenteric ganglion of the guinea-pig: Immunohistochemical studies with antisera to substance $P$, enkephalin, vasoactive intestinal polypeptide, cholecystokinin and bombesin. Neuroscience 9: 191-211.

Edin, R., H. Ahlman, and J. Kewenter (1979) The vagal control of the feline pyloric sphincter. Acta Physiol. Scand. 107: 169-174.

Elde, R., T. Hökfelt, O. Johansson, M. Schultzberg, S. Efendic, and R. Luft (1978) Cellular localization of somatostatin. Clin. Exp. Metabol. (Suppl. 1) 27: 1151-1159.

Elfvin, L.-G., and B. Lindh (1982) A study of the extrinsic innervation of the guinea pig pylorus with the horseradish peroxidase tracing technique. J. Comp. Neurol. 208: 317-324.

Everitt, B. J., T. Hökfelt, L. Terenius, K. Tatemoto, V. Mutt, and M. Goldstein (1984) Differential co-existence of neuropeptide Y (NPY)like immunoreactivity with catecholamines in the central nervous system of the rat. Neuroscience 11: 443-462.

Fahrenkrug, J., and J. H. Pedersen (1984) Development and validation of a specific radioimmunoassay for PHI in plasma. Clin. Chim. Acta 143: 183-192.

Fahrenkrug, J., and O. B. Schaffalitzky de Muckadell (1977) Radioimmunoassay of vasoactive intestinal polypeptide (VIP) in plasma. J. Lab. Clin. Med. 89: 1379-1388.

Fahrenkrug, J., and O. B. Schaffalitzky de Muckadell (1978) Distribution of vasoactive intestinal polypeptide(VIP) in the porcine central nervous system. J. Neurochem. 31: 1445-1451

Fahrenkrug, J., T. Bek, J. M. Lundberg, and T. Hökfelt (1985) VIP and PHI in cat neurons: Colocalization but variable tissue content possibly due to differential processing. Regul. Pept. 12: 21-34.

Fried, G., L. Terenius, T. Hökfelt, and M. Goldstein (1985) Evidence for the differential localization of noradrenaline and neuropeptide $Y$ (NPY) in neuronal storage vesicles isolated from rat vas deferens. J. Neurosci. 5: 450-458.

Furness, J. B., M. Costa, P. C. Emson, R. Håkanson, E. Moghimzadeh, F. Sundler, I. L. Taylor, and K. E. Chance (1983) Distribution, pathways and reactions to drug treatment of nerves with neuropeptide $\mathrm{Y}$ - and pancreatic polypeptide-like immunoreactivity in the guinea pig digestive tract. Cell Tissue Res. 234: 71-92.

Gabella, G. (1979) Innervation of the gastrointestinal tract. Int. Rev. Cytol. 59: 129-193.

Goldstein, M., B. Anagnoste, L. S. Freedman, M. Roffman, R. P. Ebstein, D. H. Park, K. Fuxe, and T. Hökfelt (1973) Characterization, localization and regulation of catecholamine synthesizing enzymes. In Frontiers in Catecholamine Research, E. Usdin and S. Snyder, eds., pp. 69-78, Pergamon, New York.

Hartman, B. K., D. Zide, and S. Udenfriend (1972) The use of dopamine $\beta$-hydroxylase as a marker for the noradrenergic pathways of the central nervous system in the rat. Proc. Natl. Acad. Sci. USA 69: $2722-2726$

Hassal, C. J. S., and G. Burnstock (1984) Neuropeptide Y-like immunoreactivity in cultured intrinsic neurons of the heart. Neurosci. Lett. 52: 111-115.

Hökfelt, T., L.-G. Elfvin, R. Elde, M. Schultzberg, M. Goldstein, and R. Luft (1977a) Occurrence of somatostatin-like immunoreactivity in some peripheral sympathetic noradrenergic neurons. Proc. Natl. Acad. Sci. USA 74: 3587-3591.

Hökfelt, T., L.-G. Elfvin, M. Schultzberg, K. Fuxe, S. I. Said, V. Mutt, and M. Goldstein (1977b) Immunohistochemical evidence of vasoactive intestinal polypeptide-containing neurons and nerve fibers in sympathetic ganglia. Neuroscience $2: 885-896$.

Hökfelt, T., M. Schultzberg, O. Johansson, A. Ljungdahl, L.-G. Elfvin, R. Elde, L. Terenius, G. Nilsson, S. Said, and M. Goldstein (1978) Central and peripheral peptide producing neurons. In Gut Hormones, S. R. Bloom, ed., pp. 423-433, Churchill Livingstone, Edinburgh. 
Hökfelt, T., G. Skagerberg, L. Skirboll, and A. Björklund (1983) Combination of retrograde tracing and neurotransmitter histochemistry. In Handbook of Chemical Neuroanatomy, Vol. 1, A. Björklund and T. Hökfelt, eds., pp. 228-285, Elsevier, Amsterdam.

Itoh, N., K. Obata, N. Yanaihara, and H. Okamoto (1983) Human preprovasoactive intestinal polypeptide contains a novel PHI-27-like peptide, PHM-27. Nature 304: 547-549.

Krulich, L., A. P. S. Dhariwal, and S. M. McCann (1968) Stimulatory and inhibitory effects of purified hypothalamic extracts on growth hormone release from pituitary in vitro. Endocrinology 83: 783-790.

Lindh, B., C.-J. Dalsgaard, L.-G. Elfvin, T. Hökfelt, and A. C. Cuello (1983) Evidence of substance $P$ immunoreactive neurons in dorsal root ganglia and vagal ganglia projecting to the guinea pig pylorus. Brain Res. 269: 365-369.

Lundberg, J. M., T. Hökfelt, A. Änggård, L. Terenius, R. Flde, K. Markey, M. Goldstein, and J. Kimmel (1982a) Organizational principles in the peripheral sympathetic nervous system: Subdivision by coexisting peptides (somatostatin-, avian pancreatic polypeptide-, and vasoactive intestinal polypeptide-like immunoreactive materials). Proc. Natl. Acad. Sci. USA 79: 1303-1307.

Lundberg, J. M., L. Terenius, T. Hökfelt, C. R. Martling, K. Tatemoto, V. Mutt, J. Polak, S. Bloom, and M. Goldstein (1982b) Neuropeptide $\mathrm{Y}$ (NPY)-like immunoreactivity in peripheral noradrenergic neurons and effects of NPY on sympathetic function. Acta Physiol. Scand. 116: 477-480.

Lundberg, J. M., L. Terenius, T. Hökfelt, and M. Goldstein (1983) High levels of neuropeptide $Y$ in peripheral noradrenergic neurons in various mammals including man. Neurosci. Lett. 42: 167-172.

Lundberg, J. M., J. Fahrenkrug, T. Hökfelt, C.-R. Martling, O. Larsson, K. Tatemoto, and A. Änggård (1984a) Coexistence of peptide HI (PHI) and VIP in neurons regulating blood flow and bronchial smooth muscle tone in various mammals including man. Peptides 5: 593606.

Lundberg, J. M., L. Terenius, T. Hökfelt, and K. Tatemoto (1984b) Comparative immunohistochemical and biochemical analysis of pancreatic polypeptide-like peptides with special reference to presence of neuropeptide $Y$ in central and peripheral neurons. J. Neurosci. 4: 2376-2386.

Lundberg, J. M., A. Änggård, J. Pernow, and T. Hökfelt (1985) Neuropeptide $\mathrm{Y}$-, substance $\mathrm{P}$ - and VIP-immunoreactive nerves in cat spleen in relation to autonomic vascular and volume control. Cell Tissue Res. 239: 9-18.

Markey, K. A., S. Kondo, L. Shenkman, and M. Goldstein (1980) Purification and characterization of tyrosine hydroxylase from a clonal pheochromocytoma cell line. Mol. Pharmacol. 17: 79-85.

Mutt, V., and S. I. Said (1974) Structure of the porcine vasoactive intestinal octacosapeptide: The amino-acid sequence. Use of kallikrein in its determination. Eur. J. Biochem. 42:581-589.
Pease, D. C. (1962) Buffered formaldehyde as a killing agent and primary fixative for electron microscopy. Anat. Rec. 142: 342.

Said, S. I., and V. Mutt (1970) Polypeptide with broad biological activity. Isolation from small intestinc. Science 169: 1217-1218.

Samuelson, U. E., and C. J. Dalsgaard (1985) Effects and localization of neuropeptide $\mathrm{Y}$ in human fallopian tube. Neurosci. Lett. 58: 4954.

Schmued, L. C., L. W. Swanson, and P. E. Sawchenko (1982) Some fluorescent counterstains for neuroanatomical studies. J. Histochem. Cytochem. 30: 123-128.

Schultzberg, M., T. Hökfelt, G. Nilsson, L. Terenius, J. F. Rehfeld, M. Brown, R. Elde, M. Goldstein, and S. Said (1980) Distribution of peptide- and catecholamine-containing neurons in the gastrointestinal tract of rat and guinea-pig: Immunohistochemical studies with antisera to substance $P$, vasoactive intestinal polypeptide, enkephalins, somatostatin, gastrin/cholecystokinin, neurotensin and dopamine $\beta$-hydroxylase. Neuroscience 5: 689-744.

Skirboll, L., T. Hökfelt, G. Norell, O. Phillipson, H. G. J. M. Kuypers, M. Bentivoglio, C. E. Catsman-Berrevoets, T. J. Visser, H. Steinbusch, A. Verhofstad, A. C. Cuello, M. Goldstein, and M. Brownstein (1984) A method for specific transmitter identification of retrogradely labeled neurons: Immunofluorescence combined with fluorescence tracing. Brain Res. Rev. 8: 99-127.

Sundler, F., E. Moghimzadeh, R. Hákanson, M. Ekelund, and P. Emson (1983) Nerve fibers in the gut and pancreas of rat displaying neuropeptide-Y immunoreactivity. Cell Tissue Res. 230: 487-493.

Tatemoto, K. (1982) Neuropeptide Y: Complete amino-acid sequence of the brain peptide. Proc. Natl. Acad. Sci. USA 79: 5485-5489.

Tatemoto, K., and V. Mutt (1980) Isolation of two novel candidate hormones using a chemical method for finding naturally occurring polypeptides. Nature 285: 417-418.

Tatemoto, K., and V. Mutt (1981) Isolation and characterization of the intestinal peptide porcine PHI (PHI-27), a new member of the glucagon-secretin family. Proc. Natl. Acad. Sci. USA 78: 6603-6607.

Tatemolo, K., M. Carlquist, and V. Mutt (1982) Neuropeptide YA novel brain peptide with structural similarities to peptide $Y Y$ and pancreatic polypeptide. Nature 296: 659-660.

Tramu, G., A. Pillez, and J. Leonardelli (1978) An efficient method of antibody elution for the successive or simultaneous localization of two antigens by immunocytochemistry. J. Histochem. Cytochem. 26: 322-324.

Yanaihara, N., K. Nokihara, C. Yanaihara, T. Iwanaga, and T. Fujita (1983) Immunocytochemical demonstration of PHI and its co-existence with VIP in intestinal nerves of the rat and pig. Arch. Histol. Jpn. 46: 575-581.

Zamboni, L., and C. de Martino (1967) Buffered picric acid formaldehyde: A new rapid fixative for electron microscopy. J. Cell Biol. 35: $148 \mathrm{~A}$. 